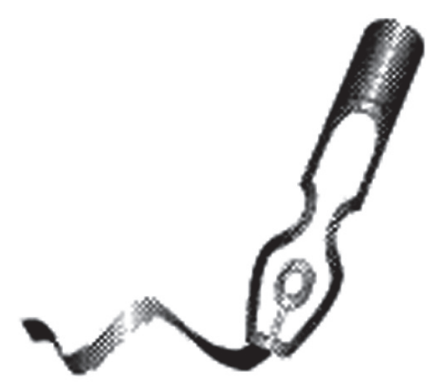

\title{
Coronavirus y personal de la salud
}

En las últimas semanas hemos visto como una nueva enfermedad viral puede hacer colapsar a nuestros sistemas sanitarios y generar caos y miedo en la población. El nuevo coronavirus (COVID-19) ha infectado a más de 200.000 personas, afectando inicialmente a Wuhan, China, y que ya compromete a la gran mayoría de los países del mundo. Este virus provoca cuadros respiratorios agudos, que van desde síntomas leves en gente joven, hasta neumonías graves en adultos mayores. Es nuestro deber como personal de la salud enfrentar esta situación y colaborar en la contención de la pandemia.

Al mismo tiempo debemos velar por nuestra seguridad laboral. Debido a la alta capacidad de transmisión de este virus, y a pesar de tomar todas las medidas de precaución, el personal de la salud se encuentra muy expuesto a contraer el virus COVID-19. El riesgo de contagio para el personal de la salud proviene tanto de los pacientes, como de colegas que aún se encuentren asintomáticos. Es importante que afrontemos esta pandemia en forma responsable, coordinada para impedir numerosos contagios entre el personal de la salud. Si bien esta pandemia se ha transformado en problema mundial, no es la primera vez que la humanidad enfrenta este tipo de situaciones, con la ventaja que actualmente contamos con tecnología que nos permite realizar gran parte de las actividades en forma virtual, como videoconferencias 0 transacciones bancarias y con equipos de investigación que trabajan aceleradamente en distintas partes del mundo para el desarrollo de vacunas y tratamientos.

En relación a este nuevo número de la revista, destaco el artículo de investigación de Papuzinski y cols., quienes describen la anatomía laríngea del modelo porcino y lo proponen como modelo de entrenamiento quirúrgico. Entre los casos clínicos destaco al artículo de Silva y cols., quienes muestran el resultado exitoso de un paciente con enfermedad de Ménière bilateral que fue sometido a laberintectomía e implante coclear simultáneo. Este número incluye dos artículos de revisión: Cortese y cols. presentan el cuestionario ETDQ-7 para síntomas por disfunción tubárica, mientras que Zemelman y cols. revisan el tema de Mucoceles de cavidades paranasales.

Finalmente, les pido a todos nuestros autores que lean atentamente las instrucciones a los autores publicadas en este número y en la página web de la revista. Estas instrucciones deberán ser consideradas cuando envíen nuevos manuscritos a revisión. 